\title{
Leadership in evidence-based practice: a systematic review
}

\author{
Ursula Reichenpfader, Siw Carlfjord and Per Nilsen
}

\section{Linköping University Post Print}

\section{Tweet}

N.B.: When citing this work, cite the original article.

Original Publication:

Ursula Reichenpfader, Siw Carlfjord and Per Nilsen, Leadership in evidence-based practice: a systematic review, 2015, Leadership in Health Services, (28), 4.

http://dx.doi.org/10.1108/LHS-08-2014-0061

Copyright: Emerald

http://www.emeraldinsight.com/

Postprint available at: Linköping University Electronic Press

http://urn.kb.se/resolve?urn=urn:nbn:se:liu:diva-120935 


\section{Leadership in evidence-based practice: a systematic review}

Ursula Reichenpfader*, Siw Carlfjord and Per Nilsen

Department of Medical and Health Sciences, Division of Community Medicine, Linköping University, SE-581 83 Linköping, Sweden

*Correspondence: ursula.reichenpfader@liu.se

Siw Carlfjord: siw.carlfjord@liu.se; Per Nilsen: per.nilsen@liu.se 


\section{Structured Abstract:}

Purpose: We aimed to systematically review published empirical research on leadership as a determinant for the implementation of evidence-based practice (EBP) and to investigate leadership conceptualization and operationalization in this field.

Design/methodology/approach: A systematic review with narrative synthesis was conducted. Relevant bibliographic databases and reference lists of pertinent review articles were searched. To be included, a study had to involve empirical research and refer to both leadership and EBP in health care. Study quality was assessed with a structured instrument based on study design.

Findings: A total of 17 studies were included. Leadership was mostly viewed as a modifier for implementation success, acting through leadership support. Yet, there was definitional imprecision as well as conceptual inconsistency and studies seemed to inadequately address situational and contextual factors. Although referring to an organizational factor, the concept was mostly analysed at the individual or group level.

Research limitations/implications: The concept of leadership in implementation science seems to be not fully developed. It is unclear whether attempts to tap the concept of leadership in available instruments truly capture and measure the full range of the diverse leadership elements at various levels. Research in implementation science would benefit from a better integration of research findings from other disciplinary fields. Once a more mature concept has been established, researchers in implementation science could proceed to further elaborate operationalization and measurement.

\section{Originality/value}

Although the relevance of leadership in implementation science has been acknowledged, the conceptual base of leadership in this field has received only limited attention.

\section{Keywords}

Leadership, Conceptualization, Measurement, Evidence-based practice, Systematic review 


\section{Background}

Despite widespread acceptance of the importance of implementing evidence-based practice (EBP) and the use of findings from scientific research in clinical practice, many patients still do not receive treatments with proven effectiveness or may receive care that is of little benefit or harmful (Dopson et al., 2002, Greenhalgh et al., 2004, Oxman et al., 1995). Implementation science has emerged as a vital interdisciplinary research field to address the challenges associated with the gap identified between the production and use of evidence in various settings. Explanations for this gap have largely focused on the characteristics of the individual provider, such as limited access to research, poor confidence in identifying and critically appraising evidence and perceived time restrictions to integrate research into clinical practice (Rycroft-Malone, 2008, Estabrooks et al., 2003, Squires et al., 2011).

However, within the field of implementation science, there has been increasing recognition of the role of the organizational context in the implementation of EBP (Durlak and DuPre, 2008, Greenhalgh et al., 2004, Fixsen et al., 2005). Leadership has been identified as an important contextual dimension (Taylor et al., 2011, Stetler et al., 2011, Newton et al., 2003); leadership commitment and active interest are behaviours that can positively affect the effectiveness of implementation (Helfrich et al., 2007). In addition, leaders' influence on the subjective norms of potential adopters through interpersonal networks and communication must be considered (Leeman et al., 2007). Although there is no universally agreed definition of leadership, many conceptualizations reflect the assumption that leadership involves a process of exerting intentional influence by one person over another person or group in order to achieve a certain outcome in a group or organization (Gill, 2012, Yukl, 2006). There is evidence from outside the health care field of the influence of leadership on organizational culture, organizational performance (Ogbonna, 2000), organizational change (Battilana et al., 2010) and organizational innovation (Denti and Hemlin, 2012, Siegel and Kaemmerer, 1978).

Although the relevance of leadership in implementation science has been acknowledged, there seems to have been little empirical research on this concept in this field. Thus, the role of leadership in the implementation of EBP and the processes through which leaders can affect implementation success are largely unknown (Long et al., 2013, RycroftMalone et al., 2011, Wallin et al., 2006, Wong et al., 2013, Aarons et al., 2014). Therefore, the aim of this study was to systematically review published empirical research on leadership as a determinant for the implementation of EBP in health care and to investigate the conceptualization and operationalization of leadership in the field of implementation science.

\section{Methods}

Our approach is based on a conceptual scoping review (Levac et al., 2010) where we attempt to examine the range of research and to identify potential research gaps in the existing literature. The research question was formulated as follows: Based on an exploratory systematic review of empirical health care implementation studies on the concept of leadership, how is the leadership concept applied and contextualized? How do study authors define and specify the concept of leadership or its essential components and how is the construct measured? 
The electronic databases PubMed and The Cochrane Library including the Cochrane Database of Systematic Reviews were searched and a separate search was conducted via the search function at the Implementation Science journal website (see Electronic Supplementary Material, Table S1 for search history). Medical Subject Headings as search terms when available were used or key words when appropriate. Search terms for leadership and research utilization or EBP were combined. All electronic searches were limited to "English language”, "German language” or "Swedish language” In addition, reference lists of pertinent review articles, key publications and commentaries were searched manually. All searches were conducted in October and November 2013. Due to limited resources, abstracts and full text articles could not be screened independently. Studies available in abstract form only were excluded. Eligibility criteria with respect to study design, publication type, study aim, setting, participants and outcomes were developed.

To be eligible for inclusion, a study had to explicitly refer to leadership as a construct (or leaders or leaders' characteristics or leadership skills) in relation to the outcome of EBP or research use (research utilization, knowledge transfer, knowledge translation, knowledge utilization) in health care. Thus, studies exploring only general barriers or organizational factors affecting implementation outcomes were excluded. In addition, studies on instrument development or validation related to leadership and studies focusing only on conducting research (as opposed to research use or knowledge translation) were excluded. Studies exploring the effect of knowledge brokers, local opinion leaders, external facilitators, facilitation or change agents, as well as studies on leadership interventions (e.g. leadership development interventions, leadership training programs) were also excluded. No limitations with respect to a specific study design were applied.

One member of the research team (UR) was responsible for reading the abstracts of all the articles identified in this first search and applying the inclusion/exclusion criteria using an abstract screening tool. Inclusion/exclusion criteria were developed and discussed by all members of the research team (UR, SC, PN) and UR piloted the inclusion/exclusion criteria with a subset of abstracts retrieved from PubMed. Two members of the research team (SC and PN) reviewed the search terms, the search strategy, the abstract screening strategy, and the data abstraction criteria.

Data were abstracted from each included study by one member of the research team (UR) using predefined criteria (study aims, study design and methods; study participants; type of outcomes; health care setting and country where the study was conducted; main findings with respect to leadership: underlying theory, concept or framework; leadership construct; leadership operationalization and measurement; outcomes; type of data analysis; level of analysis, and stage of change process, i.e. pre-implementation, implementation, postimplementation).

Study quality or study reporting quality was assessed with a structured instrument based on the design of the individual study: Critical Appraisal Skills Program (CASP) for qualitative studies (Critical Appraisal Skills, 2013), the Assessment of Multiple Systematic Reviews (AMSTAR) tool for systematic reviews (Shea et al., 2007), and the Mixed Methods Appraisal Tool for mixed methods studies (Pluye et al., 2011). As there is currently no consensus guideline for survey research available, the data abstraction form in Bennett et al. (Bennett et al., 2010) was utilized. The operationalization of the concept was analysed based 
on all studies using a survey approach and on qualitative studies providing published information on the respective interview guides.

\section{Results}

Our searches identified 1149 citations. We screened 144 full text articles for eligibility of which 17 were included in the study (Figure 1) (Aarons, 2006, Bergstrom et al., 2012, Boström et al., 2007, Brown and McCormack, 2011, Cummings et al., 2010, Damschroder et al., 2011, Estabrooks et al., 2007, Forsman et al., 2012, Gifford et al., 2007, Gifford et al., 2006, Hagedorn and Heideman, 2010, Ring et al., 2005, Sandstrom et al., 2011, Schultz and Kitson, 2010, Sharp et al., 2004, Stetler et al., 2009, Williams et al., 2011). Of these, two studies were assessed as high quality, nine were rated moderate quality, and five studies were of poor quality (methodological and/or reporting quality). The quality of a study using an action research approach could not be reliably determined with the available instruments.

\section{Study characteristics}

With regard to the professional groups involved, we found that 11 of the 17 studies (65\%) referred to nursing; the remaining studies involved a variety of health professionals (physicians, clinical pharmacists, physical therapists, behavioural, nutritional, and mental health care practitioners). One of the studies was conducted by a multinational team in Uganda; the other studies were conducted in industrialized countries (Australia, Canada, Sweden, United Kingdom, United States). Seven of the 17 studies used a survey research approach, three were conducted with a mixed methods approach, five were qualitative studies, and two were (narrative) systematic reviews (Table 1 summarizes the main characteristics of the 17 studies included).

\section{HERE (if possible): TABLE 1}

A clear classification of the outcome was possible for 15 of the 17 studies; six referred to implementation effectiveness (defined by a variety of measures, e.g. use of clinical guidelines, adoption, fidelity, or maintenance of a specific evidence-based program), seven referred to health professionals' self-reported research use (or knowledge translation into practice, or attitudes towards research use, or attitudes towards adoption of EBPs), and two included both research use and implementation effectiveness.

Most of the study authors used an implementation model, conceptual framework or a theory for making assumptions on how determinants related to the outcome. In eight of the studies (Bergstrom et al., 2012, Boström et al., 2007, Brown and McCormack, 2011, Cummings et al., 2010, Estabrooks et al., 2007, Hagedorn and Heideman, 2010, Schultz and Kitson, 2010, Sharp et al., 2004), the authors referred to the Promoting Action on Research Implementation in Health Services (PARiHS) framework (Kitson et al., 1998). The PARiHS framework was used as an organizing or mapping tool in all of these studies, either for data structuring and selection of variables, as a heuristic for coding qualitative data, in instruments based on the framework, or in interview guide development. 


\section{Conceptualization of leadership}

In all of the included 17 studies, leadership was understood as a modifier of implementation effectiveness or research use, where leaders' positive influences and direct or indirect facilitative behaviours on implementation success were emphasized. Most studies explored leadership within a range of other contextual or organizational factors. In a few studies, the terms leadership, leader and management were used interchangeably (Boström et al., 2007, Damschroder et al., 2011, Forsman et al., 2012, Gifford et al., 2007, Sandstrom et al., 2011). Leadership was mostly conceptualized as leadership support (or management support). In nine of the 17 studies, the authors described leadership behaviours referring to the concept of transformational leadership (Table 2 gives an overview of the main findings).

\section{HERE (if possible): TABLE 2}

All studies referred to the importance of leadership, although they varied in the selection of specific dimensions from the whole range of leadership functions. Authors addressed both task-oriented leadership (goal emphasis, work facilitation, strategic thinking) and relations-oriented leadership (interaction facilitation, support, team building); the changeoriented leadership dimension (driving innovation, visionary thinking) was addressed less often. Nine of the 17 studies (Aarons, 2006, Bergstrom et al., 2012, Boström et al., 2007, Brown and McCormack, 2011, Cummings et al., 2010, Estabrooks et al., 2007, Hagedorn and Heideman, 2010, Schultz and Kitson, 2010, Stetler et al., 2009) addressed transformational leadership. Only one study addressed leadership in connection with specific or desirable attributes of a leader, distinguishing trainable skills from innate traits (Williams et al., 2011).

There was some variation with respect to the level of formal authority of leadership, yet all of the studies referred to some formally assigned hierarchical role. Only one study analysed leadership at the dyadic level of leader-follower (or supervisor-supervisee level), thus reflecting a close and supervisory relationship (Aarons, 2006). With a few exceptions, authors referred to the group or unit level as the formal authority for leadership, involving various titles (nurse manager, nursing manager, unit manager, ward manager, unit directors, administrators, clinical resource nurses, program manager) (Bergstrom et al., 2012, Boström et al., 2007, Brown and McCormack, 2011, Cummings et al., 2010, Damschroder et al., 2011, Gifford et al., 2007, Gifford et al., 2006, Ring et al., 2005, Sandstrom et al., 2011, Schultz and Kitson, 2010, Sharp et al., 2004). One study referred to both the dyadic and the organizational level (Estabrooks et al., 2007), and one to a range of upper and lower management levels (from unit nurse director to chief nurse) (Stetler et al., 2009). One of the few studies truly exploring leadership at the organizational level used the Organizational Readiness to Change Assessment instrument, where leadership was assessed at the senior leadership level in a respondent's organization (Hagedorn and Heideman, 2010).

\section{Operationalization of leadership}

Nine of the 17 studies provided information that allowed assessment of how leadership was operationalized (Aarons, 2006, Boström et al., 2007, Brown and McCormack, 2011, Cummings et al., 2010, Estabrooks et al., 2007, Forsman et al., 2012, Hagedorn and Heideman, 2010, Schultz and Kitson, 2010, Stetler et al., 2009). The studies varied greatly with respect to how leadership was measured and how instruments were used. 
Leadership as a supporting or hindering factor in direct relation to EBP was assessed in seven studies (Boström et al., 2007, Brown and McCormack, 2011, Cummings et al., 2010, Hagedorn and Heideman, 2010, Schultz and Kitson, 2010, Estabrooks et al., 2007, Forsman et al., 2012). However, validated instruments were used in only three of those studies: two studies (Cummings et al., 2010, Schultz and Kitson, 2010) used the Alberta Context Tool (ACT) (Estabrooks et al., 2009) and one study (Hagedorn and Heideman, 2010) used the Organizational Readiness to Change Assessment (ORCA) (Helfrich et al., 2009). In addition, two further studies (Aarons, 2006, Forsman et al., 2012) used instruments with a different approach in which leadership was addressed in relation to an outcome other than EBP; the authors then used data from this instrument in combination with an additional instrument developed to measure some aspect of EBP. In one of these two studies (Forsman et al., 2012), leadership dimensions were measured with the General Nordic Questionnaire for Psychological and Social Factors at Work (QPSNordic), a validated instrument to assess psychological, social, and organizational work conditions (Wannstrom et al., 2009). Data from this instrument were than related to information on the outcome, research use, measured by a non-validated instrument. Similarly, in the study by Aarons (Aarons, 2006), the Multifactor Leadership Questionnaire (Avolio et al., 1999), a validated scale of transformational leadership, was used to analyse the association with providers' attitudes towards EBP.

Diverse leadership behaviours were tapped in the instruments administered; most of them addressed some form of support (at various levels), such as relations-oriented behaviours (i.e. solicits opinions; enhances collaboration; promotes team building; empowers, mentors and coaches; facilitates staff development), task-oriented behaviours (i.e. provides adequate staffing and resources; establishes project schedule and clarifies deliverables; sets clear goals and establishes role clarity; supervises and instructs), or, rarely, change-oriented behaviours (sets high priorities on success of innovation; is accessible, visible and available during implementation; describes clear strategic vision; appoints champions; rewards innovation and creativity, motivates change, sets high priority on successes). In three studies (Boström et al., 2007, Estabrooks et al., 2007, Gifford et al., 2007), leadership was analysed using only one or two (rather generically worded) items.

\section{Discussion}

This literature synthesis was undertaken to investigate how leadership has been conceptualized and operationalized in implementation science. We identified 17 studies that fulfilled the inclusion criteria. The nursing field dominated and all but one study were conducted in industrialized countries in a variety of health care settings. No experimental study was identified.

The authors of the 17 studies predominantly discussed leadership as a modifier or an intermediate factor for implementation success, yet the hypothesized mechanisms to affect outcomes were not specified and could not be tested with the study designs that were applied. Leadership was mostly used with a positive connotation; the studies addressed it as a potential supporting factor, rather than viewing lack of such support as a hindering factor. 
Overall, the authors seemed to conceptualize leadership as supervisory or managerial leadership, thus not differentiating between the concepts of leadership and management. There has been some controversy in leadership theory whether leadership and management are essentially different concepts (Zaleznik, 2004) implicating mutually exclusive roles of leaders, but newer leadership theories argue for a more flexible model integrating both, albeit distinct, functions carried out by one person, depending on situational and contextual factors (Yukl and Lepsinger, 2005, Kotter, 1990). In the leadership literature, supervisory leadership refers to behaviours aiming to provide guidance, support and feedback in day-to-day situations at the work unit level; management, however, is understood as the function implementing leaders' strategy but mainly deals with coordinative and administrative tasks (House and Aditya, 1997, Yukl, 1989). Thus, by not differentiating between managerial and leadership functions, the authors did not adequately address the situational and contextual factors relevant to understand the processes of how leadership might affect successful implementation. While managerial and leadership functions can complement each other and show some overlap, not adequately differentiating between these two distinct functions has research implications in that it obfuscates leadership's conceptual base; moreover, it can have practical impacts when designing leadership development programs.

Many studies lacked a precise definition of the term leadership and there was conceptual inconsistency among the studies. The vagueness of conceptual definitions of leadership in the implementation science literature somewhat reflects the discourse within leadership research (Kempster and Parry, 2011). The concept of leadership is continually evolving, but leadership theories, specifically transformational and charismatic leadership theories, have been criticized for their conceptual and measurement weaknesses (Kelloway et al., 2000, Yukl, 1999a).

Nine of the 17 studies addressed transformational leadership, but the authors mostly referred to facilitative functions, such as general support, mentoring, or participative decision making. Hence, the authors' conceptualizations reflected only a segment of leader behaviour described in transformational leadership theories (Avolio and Bass, 1988, Avolio et al., 1999, Podsakoff et al., 1996). According to transformational leadership theories, a transformational leader's effect on followers' motivation and performance can be explained by his or her attributes and behaviours (Avolio et al., 1999, Yukl, 1999b). In an idealized manner, the leader transforms and motivates followers through his or her idealized influence (or charisma), intellectual stimulation and individual consideration (Avolio and Bass, 1988). A transformational leader articulates a vision that is appealing and inspiring to followers, provides a role model for highly ethical behaviour, is able to raise follower awareness for transcendent collective interests, and helps followers achieve extraordinary goals (Avolio and Bass, 1988, Bass and Avolio, 1994). However, transformational leadership as used in the 17 implementation science studies referred to more mundane and practical functions. According to this conceptualization, transformational leader behaviours were described as communicating organizational values, clarifying roles, or showing personal support, and less on being visionary.

Although most of the study authors stressed the importance of leadership as an organizational factor, the concept was mostly analysed at the individual or group level; the authors did not address the larger organizational environment in which the unit was 
embedded. Thus, there was a mismatch with respect to the level at which leadership was conceptualized and the level at which it was measured. Although it has been observed in organizational and management research that leadership operates differently at the individual, group and organizational levels (Day and Harrison, 2007), such complexity was not captured in the 17 studies. It has been stated elsewhere that factors influencing implementation success are thought to interact dynamically (Helfrich et al., 2010) and that effects of leadership on organizational outcomes can result from multiple levels of leadership simultaneously (O'Reilly et al., 2010), requiring coordination and collaboration between the different leadership levels and units (Yukl and Lepsinger, 2005). Furthermore, recent developments in leadership theory calling for an understanding of leadership more appropriate for collaborative contexts seem to reflect a move away from the traditional view on leadership "as commanding, telling, persuading, influencing, motivating - conceived as activities in which there is a point of origin (leaders) and a point of reception (followers)" (Drath 2008, p.651). In the same vein, collaborative leadership has been described as a new leadership style embedded in a collective leadership culture, including formal and informal leadership roles, requiring individual and collective leadership skills depending on situational and contextual circumstances (West et al., 2014).

Thus, to better understand a hypothesized supporting factor, authors should be more specific when describing context factors, potential dynamics and different types of leadership behaviour and relationships in future studies.

The maturity of a concept can be assessed critically in a qualitative process against a set of four criteria: clarity of definition; characteristics or attributes; preconditions and outcomes of the described concept; delineation of concept boundaries (Morse et al., 1996). Judged against these criteria, the concept of leadership in implementation science does not seem to have been fully developed, given the inconsistencies in its use, unclear definition, that its distinguishing features have not been fully identified and conceptual boundaries not clearly demarcated. It is unclear whether attempts to tap the concept of leadership in available instruments truly capture and measure the full range of the diverse elements of leadership at various levels relevant to implementation success.

Several of the studies included in this literature synthesis had obvious methodological deficiencies. Some of the survey instruments did not assess criterion and construct validity with respect to measuring leadership. Furthermore, data from instruments with sufficient psychometric properties to measure leadership were related to outcome data from an instrument lacking appropriate psychometric properties. Many instruments measuring the outcome (mostly research use) used self-reported measures without demonstrated validity. Not all of the mixed methods studies appropriately considered the relevance of this approach with respect to the research question or effectively integrated qualitative and quantitative data. Some of the qualitative data lacked a clear conceptual framework and used small samples selected only from a specific group, making it impossible to explore a full range of responses. One study was conducted as a secondary analysis of qualitative data not generated for the research questions addressed.

This literature synthesis has limitations that have to be acknowledged when interpreting the results. We did not conduct a comprehensive literature search. We restricted searches to primary research published in peer-reviewed journals in only two bibliographic 
(although relevant and large) databases. Thus, we did not search grey literature and might have missed relevant but unpublished research. A further limitation of our work is that study selection and quality assessment were not done independently. Also, we did not define or specify specific outcomes of EBP a priori, so that potentially relevant studies could have been missed, also due to poor indexing of this concept in medical bibliographic databases.

\section{Conclusions}

Based on the 17 studies analysed, our narrative synthesis on leadership found that there is considerable variety in how leadership is addressed in current implementation science studies conducted in health care settings. Conceptualization of leadership in implementation science is characterized by imprecise definitions and inconsistent use of terms, thereby hindering a clear understanding of this concept's role as a determinant of EBP and putting into question efforts of operationalization in this field. One example is the poor differentiation between management and leadership, a subject that needs further elaboration. The weak conceptual base has also practical implications affecting leadership development initiatives.

The findings of this study have a number of implications for future implementation science research. We identified conceptual gaps suggesting a need for theoretical advancement of the concept of leadership within implementation science. Because the concept of leadership does not seem to be sufficiently developed, differentiated and clearly positioned within the field of implementation science, it is unclear how useful its application in research and practice is at this point in time. Ongoing efforts to establish and refine terms and definitions as well as to promote consistent use of these terms and definitions of leadership within implementation science would benefit from a better integration of research findings from other disciplinary fields (e.g. organizational science). When a more mature concept has been established, researchers in implementation science could then proceed to further elaborate operationalization and measurement.

\section{Competing interests}

The authors declare that they have no competing interests.

\section{Acknowledgements}

No extra funding was received to conduct this review.

\section{References}

AARONS, G. A. 2006. Transformational and transactional leadership: association with attitudes toward evidence-based practice. Psychiatric services (Washington, D.C.), 57, 1162-1169.

AARONS, G. A., EHRHART, M. G. \& FARAHNAK, L. R. 2014. The Implementation Leadership Scale (ILS): development of a brief measure of unit level implementation leadership. Implement Sci, 9, 45.

AVOLIO, B. J. \& BASS, B. M. 1988. Transformational leadership, charisma, and beyond. In: HUNT, J. G., BALIGA, B. R., DACHLER, H. P. \& SCHRIESHEIM, C. A. (eds.) Emerging leadership vitas. Lexington, MA.: Lexington Books. 
AVOLIO, B. J., BASS, B. M. \& JUNG, D. I. 1999. Re-examining the components of transformational and transactional leadership using the Multifactor Leadership. Journal of Occupational and Organizational Psychology, 72, 441-462.

BASS, B. M. \& AVOLIO, B. J. 1994. Improving organizational effectiveness through transformational leadership, Thousand Oaks, CA, Sage.

BATTILANA, J., GILMARTIN, M., SENGUL, M., PACHE, A. C. \& ALEXANDER, J. A. 2010. Leadership competencies for implementing planned organizational change. Leadership Quarterly, $21,422-438$.

BENNETT, C., KHANGURA, S., BREHAUT, J. C., GRAHAM, I. D., MOHER, D., POTTER, B. K. \& GRIMSHAW, J. M. 2010. Reporting guidelines for survey research: an analysis of published guidance and reporting practices. PLoS medicine, 8, e1001069.

BERGSTROM, A., PETERSON, S., NAMUSOKO, S., WAISWA, P. \& WALLIN, L. 2012. Knowledge translation in Uganda: a qualitative study of Ugandan midwives' and managers' perceived relevance of the sub-elements of the context cornerstone in the PARIHS framework. Implementation science : IS, 7, 117-5908-7-117.

BOSTRÖM, A. M., WALLIN, L. \& NORDSTRÖM, G. 2007. Evidence-based practice and determinants of research use in elderly care in Sweden. Journal of Evaluation in Clinical Practice, 13, 665-673.

BROWN, D. \& MCCORMACK, B. G. 2011. Developing the practice context to enable more effective pain management with older people: an action research approach. Implementation science : IS, 6, 9-5908-6-9.

CRITICAL APPRAISAL SKILLS, P. 2013. RE: Qualitative Research Checklist 31.05.13. Public Health Resource Unit, Institute of Health Science, Oxford.

CUMMINGS, G. G., HUTCHINSON, A. M., SCOTT, S. D., NORTON, P. G. \& ESTABROOKS, C. A. 2010. The relationship between characteristics of context and research utilization in a pediatric setting. BMC health services research, 10, 168-6963-10-168.

DAMSCHRODER, L. J., GOODRICH, D. E., ROBINSON, C. H., FLETCHER, C. E. \& LOWERY, J. C. 2011. A systematic exploration of differences in contextual factors related to implementing the MOVE! weight management program in VA: a mixed methods study. BMC health services research, 11, 248-6963-11-248.

DAY, D. V. \& HARRISON, M. M. 2007. A multilevel, identity-based approach to leadership development. The Future of Leadership Development, 17, 360-373.

DENTI, L. \& HEMLIN, S. 2012. Leadership and Innovation in Organizations:: a Systematic Review of Factors that Mediate Or Moderate the Relationship. International Journal of Innovation Management, 16, 1240007-1240001; 1240007-20.

DOPSON, S., FITZGERALD, L., FERLIE, E., GABBAY, J. \& LOCOCK, L. 2002. No magic targets! Changing clinical practice to become more evidence based. Health Care Manage Rev, 27, 35-47.

DRATH, W. H., MCCAULEY, C. D., PALUS, C. J., VAN VELSOR, E., O'CONNOR, P. M. G. \& MCGUIRE, J. B. 2008. Direction, alignment, commitment: Toward a more integrative ontology of leadership. The Leadership Quarterly, 19, 635-653.

DURLAK, J. A. \& DUPRE, E. P. 2008. Implementation matters: a review of research on the influence of implementation on program outcomes and the factors affecting implementation. Am J Community Psychol, 41, 327-50.

ESTABROOKS, C. A., FLOYD, J. A., SCOTT-FINDLAY, S., O'LEARY, K. A. \& GUSHTA, M. 2003. Individual determinants of research utilization: a systematic review. J Adv Nurs, 43, 50620.

ESTABROOKS, C. A., MIDODZI, W. K., CUMMINGS, G. G. \& WALLIN, L. 2007. Predicting research use in nursing organizations: A multilevel analysis. Nursing Research, 56, S7-S23.

ESTABROOKS, C. A., SQUIRES, J. E., CUMMINGS, G. G., BIRDSELL, J. M. \& NORTON, P. G. 2009. Development and assessment of the Alberta Context Tool. BMC health services research, 9, 234-6963-9-234. 
FIXSEN, D. L., NAOOM, S. F., BLASE, K. A., FRIEDMAN, R. M. \& WALLACE, F. 2005. Implementation research: A synthesis of the literature, Tampa, FL, University of South Florida, Louis de la Parte Florida Mental Health Institute, The National Implementation Research Network.

FORSMAN, H., RUDMAN, A., GUSTAVSSON, P., EHRENBERG, A. \& WALLIN, L. 2012. Nurses' research utilization two years after graduation--a national survey of associated individual, organizational, and educational factors. Implementation science : IS, 7, 465908-7-46.

GIFFORD, W., DAVIES, B., EDWARDS, N., GRIFFIN, P. \& LYBANON, V. 2007. Managerial leadership for nurses' use of research evidence: an integrative review of the literature. Worldviews on evidence-based nursing / Sigma Theta Tau International, Honor Society of Nursing, 4, 126-145.

GIFFORD, W. A., DAVIES, B., EDWARDS, N. \& GRAHAM, I. D. 2006. Leadership strategies to influence the use of clinical practice guidelines. Nursing leadership (Toronto, Ont.), 19, 72-88.

GILL, R. 2012. Theory and Practice of Leadership. Second Edition, London, SAGE Publications Ltd.

GREENHALGH, T., ROBERT, G., MACFARLANE, F., BATE, P. \& KYRIAKIDOU, O. 2004. Diffusion of innovations in service organizations: systematic review and recommendations. The Milbank quarterly, 82, 581-629.

HAGEDORN, H. J. \& HEIDEMAN, P. W. 2010. The relationship between baseline Organizational Readiness to Change Assessment subscale scores and implementation of hepatitis prevention services in substance use disorders treatment clinics: a case study. Implementation science : IS, 5, 46-5908-5-46.

HELFRICH, C. D., DAMSCHRODER, L. J., HAGEDORN, H. J., DAGGETT, G. S., SAHAY, A., RITCHIE, M., DAMUSH, T., GUIHAN, M., ULLRICH, P. M. \& STETLER, C. B. 2010. A critical synthesis of literature on the promoting action on research implementation in health services (PARIHS) framework. Implementation science : IS, 5, 82-5908-5-82.

HELFRICH, C. D., LI, Y. F., SHARP, N. D. \& SALES, A. E. 2009. Organizational readiness to change assessment (ORCA): development of an instrument based on the Promoting Action on Research in Health Services (PARIHS) framework. Implementation science : IS, 4, 385908-4-38.

HELFRICH, C. D., WEINER, B. J., MCKINNEY, M. M. \& MINASIAN, L. 2007. Determinants of implementation effectiveness: adapting a framework for complex innovations. Medical care research and review : MCRR, 64, 279-303.

HOUSE, R. J. \& ADITYA, R. N. 1997. The Social Scientific Study of Leadership: Quo Vadis? Journal of Management, 23, 409.

KELLOWAY, E. K., BARLING, J. \& HELLEUR, J. 2000. Enhancing transformational leadership: The roles of training and feedback. Leadership \& Organization Development Journal, 21, 145149.

KEMPSTER, S. \& PARRY, K. W. 2011. Grounded theory and leadership research: A critical realist perspective. Leadership Quarterly, 22, 106-120.

KITSON, A., HARVEY, G. \& MCCORMACK, B. 1998. Enabling the implementation of evidence based practice: a conceptual framework. Quality in health care : QHC, 7, 149-158.

KOTTER, J. P. 1990. What Leaders Really Do. Harvard Business Review, 68, 103-111.

LEEMAN, J., BAERNHOLDT, M. \& SANDELOWSKI, M. 2007. Developing a theory-based taxonomy of methods for implementing change in practice. Journal of Advanced Nursing, 58, 191200.

LEVAC, D., COLQUHOUN, H. \& O'BRIEN, K. K. 2010. Scoping studies: advancing the methodology. Implementation Science : IS, 5, 69-69.

LONG, J. C., CUNNINGHAM, F. C., WILEY, J., CARSWELL, P. \& BRAITHWAITE, J. 2013. Leadership in complex networks: the importance of network position and strategic action in a translational cancer research network. Implementation science : IS, 8, 122-5908-8-122.

MORSE, J. M., MITCHAM, C., HUPCEY, J. E. \& TASON, M. C. 1996. Criteria for concept evaluation. Journal of advanced nursing, 24, 385-390. 
NEWTON, J., GRAHAM, J., MCLOUGHLIN, K. \& MOORE, A. 2003. Receptivity to Change in a General Medical Practice. British Journal of Management, 14, 143-153.

O'REILLY, C. A., CALDWELL, D. F., CHATMAN, J. A., LAPIZ, M. \& SELF, W. 2010. How leadership matters: The effects of leaders' alignment on strategy implementation. Leadership Quarterly, 21, 104-113.

OGBONNA, E. 2000. Leadership style, organizational culture and performance: empirical evidence from UK companies. The international journal of human resource management, 11, 766-788.

OXMAN, A. D., THOMSON, M. A., DAVIS, D. A. \& HAYNES, R. B. 1995. No magic bullets: a systematic review of 102 trials of interventions to improve professional practice. Canadian Medical Association Journal, 153, 1423-1431.

PLUYE, P., ROBERT, E., CARGO, M., BARTLETT, G., O'CATHAIN, A., GRIFFITHS, F., BOARDMAN, F., GAGNON, M. P. \& ROUSSEAU, M. C. 2011. RE: Proposal: A mixed methods appraisal tool for systematic mixed studies reviews. .

PODSAKOFF, P. M., MACKENZIE, S. B. \& BOMMER, W. H. 1996. Transformational Leader Behaviors and Substitutes for Leadership as Determinants of Employee Satisfaction, Commitment, Trust, and Organizational Citizenship Behaviors. Journal of Management, $22,259$.

RING, N., MALCOLM, C., COULL, A., MURPHY-BLACK, T. \& WATTERSON, A. 2005. Nursing best practice statements: an exploration of their implementation in clinical practice. Journal of Clinical Nursing, 14, 1048-1058.

RYCROFT-MALONE, J. 2008. Evidence-informed practice: from individual to context. $J$ Nurs Manag, 16, 404-8.

RYCROFT-MALONE, J., WILKINSON, J. E., BURTON, C. R., ANDREWS, G., ARISS, S., BAKER, R., DOPSON, S., GRAHAM, I., HARVEY, G., MARTIN, G., MCCORMACK, B. G., STANISZEWSKA, S. \& THOMPSON, C. 2011. Implementing health research through academic and clinical partnerships: a realistic evaluation of the Collaborations for Leadership in Applied Health Research and Care (CLAHRC). Implementation science : IS, 6, 74-5908-6-74.

SANDSTROM, B., BORGLIN, G., NILSSON, R. \& WILLMAN, A. 2011. Promoting the implementation of evidence-based practice: a literature review focusing on the role of nursing leadership. Worldviews on evidence-based nursing / Sigma Theta Tau International, Honor Society of Nursing, 8, 212-223.

SCHULTZ, T. J. \& KITSON, A. L. 2010. Measuring the context of care in an Australian acute care hospital: a nurse survey. Implementation science : IS, 5, 60-5908-5-60.

SHARP, N. D., PINEROS, S. L., HSU, C., STARKS, H. \& SALES, A. E. 2004. A qualitative study to identify barriers and facilitators to implementation of pilot interventions in the Veterans Health Administration (VHA) Northwest Network. Worldviews on evidence-based nursing / Sigma Theta Tau International, Honor Society of Nursing, 1, 129-139.

SHEA, B. J., GRIMSHAW, J. M., WELLS, G. A., BOERS, M., ANDERSSON, N., HAMEL, C., PORTER, A. C., TUGWELL, P., MOHER, D. \& BOUTER, L. M. 2007. Development of AMSTAR: a measurement tool to assess the methodological quality of systematic reviews. BMC medical research methodology, 7, 10.

SIEGEL, S. M. \& KAEMMERER, W. F. 1978. Measuring the Perceived Support for Innovation in Organizations. Journal of Applied Psychology, 63, 553-562.

SQUIRES, J. E., ESTABROOKS, C. A., GUSTAVSSON, P. \& WALLIN, L. 2011. Individual determinants of research utilization by nurses: a systematic review update. Implement Sci, 6, 1.

STETLER, C. B., DAMSCHRODER, L. J., HELFRICH, C. D. \& HAGEDORN, H. J. 2011. A Guide for applying a revised version of the PARIHS framework for implementation. Implementation science : IS, 6, 99-5908-6-99.

STETLER, C. B., RITCHIE, J. A., RYCROFT-MALONE, J., SCHULTZ, A. A. \& CHARNS, M. P. 2009. Institutionalizing evidence-based practice: an organizational case study using a model of strategic change. Implementation science : IS, 4, 78-5908-4-78.

TAYLOR, S. L., DY, S., FOY, R., HEMPEL, S., MCDONALD, K. M., OVRETVEIT, J., PRONOVOST, P. J., RUBENSTEIN, L. V., WACHTER, R. M. \& SHEKELLE, P. G. 2011. What context features 
might be important determinants of the effectiveness of patient safety practice interventions? BMJ quality \& safety, 20, 611-617.

WALLIN, L., EWALD, U., WIKBLAD, K., SCOTT-FINDLAY, S. \& ARNETZ, B. B. 2006. Understanding work contextual factors: a short-cut to evidence-based practice? Worldviews on evidence-based nursing / Sigma Theta Tau International, Honor Society of Nursing, 3, 153164.

WANNSTROM, I., PETERSON, U., ASBERG, M., NYGREN, A. \& GUSTAVSSON, J. P. 2009. Psychometric properties of scales in the General Nordic Questionnaire for Psychological and Social Factors at Work (QPS): confirmatory factor analysis and prediction of certified long-term sickness absence. Scand J Psychol, 50, 231-44.

WEST, M. A., LYUBOVNIKOVA, J., ECKERT, R. \& DENIS, J.-L. 2014. Collective leadership for cultures of high quality health care. Journal of Organizational Effectiveness: People and Performance, 1, 240-260.

WILLIAMS, R., WOODELL, C., MCCARVILLE, E., DAMITZ, M., BANKS, T., MONTOYA, J., LESCH, J. K., PERETZ, P. \& LARA, M. 2011. Desired attributes and skills of program managers in translation of evidence-based interventions. Health promotion practice, 12, 82S-90S.

WONG, C. A., CUMMINGS, G. G. \& DUCHARME, L. 2013. The relationship between nursing leadership and patient outcomes: a systematic review update. Journal of nursing management, 21, 709-724.

YUKL, G. 1989. Managerial Leadership: A Review of Theory and Research. Journal of Management, 15, 251.

YUKL, G. 1999a. An evaluation of conceptual weaknesses in transformational and charismatic leadership theories. Leadership Quarterly, 10, 285.

YUKL, G. 1999b. An evaluative essay on current conceptions of effective leadership. European Journal of Work and Organizational Psychology, 8, 33-48.

YUKL, G. \& LEPSINGER, R. 2005. Why Integrating the Leading and Managing Roles Is Essential for Organizational Effectiveness. Organizational Dynamics, 34, 361-375.

YUKL, G. A. 2006. Leadership in organizations, 6th Ed., Upper Saddle River, NJ, Pearson/Prentice Hall.

ZALEZNIK, A. 2004. Managers and Leaders: Are They Different? Harvard Business Review, 82, 74-81. 
Table 1 Characteristics of the studies included

\begin{tabular}{|c|c|c|c|c|c|}
\hline Author & Participants and setting & Study design & $\begin{array}{l}\text { Underlying theory, model or } \\
\text { framework }\end{array}$ & Outcome measures & Comments \\
\hline (Aarons, 2006) & $\begin{array}{l}\text { Mental health clinicians in child } \\
\text { and adolescent mental health } \\
\text { services, United States }\end{array}$ & $\begin{array}{l}\text { Cross-sectional; web survey } \\
\text { (81\% response) }\end{array}$ & $\begin{array}{l}\text { Transformational leadership } \\
\text { theory }\end{array}$ & $\begin{array}{l}\text { Attitudes to EBP measured by } \\
\text { the Evidence-Based Practice } \\
\text { Attitude Scale (EBPAS) }\end{array}$ & $\begin{array}{l}\text { Instrument to measure } \\
\text { leadership as developed not } \\
\text { specific to EBP }\end{array}$ \\
\hline $\begin{array}{l}\text { (Bergstrom et al., } \\
\text { 2012) }\end{array}$ & $\begin{array}{l}18 \text { midwives and } 5 \text { managers at } \\
\text { community health centres and a } \\
\text { hospital in Uganda }\end{array}$ & $\begin{array}{l}\text { Qualitative study; } 2 \text { focus group } \\
\text { discussions, } 10 \text { semi-structured } \\
\text { interviews) }\end{array}$ & $\begin{array}{l}\text { The Promoting Action on } \\
\text { Research Implementation in } \\
\text { Health Services (PARiHS) } \\
\text { framework }\end{array}$ & $\begin{array}{l}\text { Process of changing practice, } \\
\text { uptake of new knowledge into } \\
\text { practice }\end{array}$ & $\begin{array}{l}\text { Study carried out in a district } \\
\text { where efforts to improve } \\
\text { neonatal health and survival } \\
\text { was ongoing }\end{array}$ \\
\hline $\begin{array}{l}\text { (Boström et al., } \\
\text { 2007) }\end{array}$ & $\begin{array}{l}\text { Nurses; rehabilitation/nursing } \\
\text { homes; } 11 \text { units; large } \\
\text { municipality in Sweden }\end{array}$ & $\begin{array}{l}\text { Cross-sectional; postal survey; } \\
\text { response } 67 \%(n=89 / 132) ; 97 \% \\
\text { of respondents female }\end{array}$ & PARiHS framework & $\begin{array}{l}\text { Research use including attitudes } \\
\text { towards research, research use in } \\
\text { daily practice (the Research } \\
\text { Utilization Questionnaire, RUQ) } \\
\text { and the Creative Climate } \\
\text { Questionnaire (CCQ) }\end{array}$ & $\begin{array}{l}\text { Small sample size; very wide } \\
\text { confidence interval in } \\
\text { multivariate model; culture } \\
\text { measured by CCQ }\end{array}$ \\
\hline $\begin{array}{l}\text { (Brown and } \\
\text { McCormack, } \\
\text { 2011) }\end{array}$ & $\begin{array}{l}\text { Nurses; abdominal surgical unit } \\
\text { with } 2 \text { wards; country not } \\
\text { reported }\end{array}$ & $\begin{array}{l}\text { Qualitative study using } \\
\text { Emancipatory Action Research } \\
\text { (EAR) approach: ethnographic } \\
\text { study with non-participant } \\
\text { observation, focus group } \\
\text { discussions, and interviews; } \\
\text { survey (83\% response) }\end{array}$ & PARiHS framework & $\begin{array}{l}\text { Putting research into practice, } \\
\text { enhanced and effective patient } \\
\text { management; the revised nursing } \\
\text { work index (NWI-R) }\end{array}$ & \\
\hline $\begin{array}{l}\text { (Cummings et al., } \\
\text { 2010) }\end{array}$ & $\begin{array}{l}\text { Paediatric and neonatal nurses; } 3 \\
\text { paediatric units at } 2 \text { academic } \\
\text { hospitals in Alberta, Canada }\end{array}$ & $\begin{array}{l}\text { Cross-sectional study, The } \\
\text { Alberta Context Tool (ACT), } \\
\text { adapted to paediatric setting, } \\
\text { survey (paper-based and } \\
\text { electronic; } 69 \% \text { response) }\end{array}$ & PARiHS framework & $\begin{array}{l}\text { Self-reported research use } \\
\text { behaviour: instrumental and } \\
\text { conceptual research use; } \\
\text { measures developed by (Wallin } \\
\text { et al., 2006) }\end{array}$ & $\begin{array}{l}\text { Cross-sectional analysis; } \\
\text { generalizability unclear }\end{array}$ \\
\hline $\begin{array}{l}\text { (Damschroder et } \\
\text { al., 2011) }\end{array}$ & $\begin{array}{l}\text { Coordinators, physicians, nursing } \\
\text { staff, physical therapy, mental } \\
\text { and behavioural health, } \\
\text { nutritional health; } 24 \text { participants } \\
\text { at } 5 \text { medical facilities; United } \\
\text { States }\end{array}$ & $\begin{array}{l}\text { Mixed methods study: semi- } \\
\text { structured telephone interviews }\end{array}$ & $\begin{array}{l}\text { Adapted model developed by } \\
\text { (Klein and Sorra, 1996) }\end{array}$ & $\begin{array}{l}\text { Implementation effectiveness } \\
\text { (operationalization based on } \\
\text { program } \\
\text { adoption/implementation and } \\
\text { fidelity) }\end{array}$ & \\
\hline $\begin{array}{l}\text { (Estabrooks et al., } \\
\text { 2007) }\end{array}$ & $\begin{array}{l}\text { Nurses; various medical, } \\
\text { surgical, rehabilitative, palliative, } \\
\text { chronic care, and emergency care } \\
\text { specialties, Alberta, Canada }\end{array}$ & $\begin{array}{l}\text { Secondary data analysis from the } \\
\text { Alberta Registered Nurse (ARN) } \\
\text { survey; mailed province-wide } \\
\text { survey; subsample of } n=4421 \\
\text { respondents ( } 53 \% \text { response) }\end{array}$ & $\begin{array}{l}\text { Context according to the } \\
\text { PARiHS framework; conceptual } \\
\text { model by (Greenhalgh et al., } \\
\text { 2004), (Dopson and Fitzgerald, } \\
\text { 2005) }\end{array}$ & $\begin{array}{l}\text { Research use (self-reported } \\
\text { general- as opposed to } \\
\text { innovation- or guideline- } \\
\text { specific); assessment of research } \\
\text { use; not directly measured, but } \\
\text { derived variable; based on } \\
\text { (Wallin et al., 2006) }\end{array}$ & \\
\hline
\end{tabular}




\begin{tabular}{|c|c|c|c|c|c|}
\hline Author & Participants and setting & Study design & $\begin{array}{l}\text { Underlying theory, model or } \\
\text { framework }\end{array}$ & Outcome measures & Comments \\
\hline $\begin{array}{l}\text { (Forsman et al., } \\
\text { 2012) }\end{array}$ & $\begin{array}{l}\text { Registered nurses two years after } \\
\text { graduation; Sweden }\end{array}$ & $\begin{array}{l}\text { Survey (wave } 2007 \text { within a } \\
\text { longitudinal survey: the } \\
\text { Longitudinal Analysis of Nursing } \\
\text { Education) }(n=845 \text { ); data on } \\
\text { organizational factors of the } \\
\text { General Nordic Questionnaire for } \\
\text { Psychological and Social Factors } \\
\text { at Work (QPSNordic) }\end{array}$ & $\begin{array}{l}\text { Adapted model based on NHS } \\
\text { staff survey model by (Michie } \\
\text { and West, 2003) }\end{array}$ & $\begin{array}{l}\text { Research use, using } 3 \text { single } \\
\text { items representing instrumental } \\
\text { (direct), conceptual (indirect), } \\
\text { and persuasive (symbolic) } \\
\text { research use (Swedish version), } \\
\text { based on (Estabrooks, 1999) }\end{array}$ & $\begin{array}{l}\text { National sample, high } \\
\text { generalizability }\end{array}$ \\
\hline $\begin{array}{l}\text { (Gifford et al., } \\
\text { 2007) }\end{array}$ & $\begin{array}{l}\text { Nurses from various settings, } \\
\text { diverse countries (United States, } \\
\text { Canada, Australia, Taiwan, } \\
\text { Sweden, United Kingdom) }\end{array}$ & $\begin{array}{l}\text { Systematic review, } 12 \text { studies } \\
\text { included ( } 8 \text { quantitative, } 4 \\
\text { qualitative), narrative synthesis }\end{array}$ & Not applicable & EBP and research use & \\
\hline $\begin{array}{l}\text { (Gifford et al., } \\
\text { 2006) }\end{array}$ & $\begin{array}{l}\text { Nurses (nursing managers, } \\
\text { administrators and clinical } \\
\text { resource nurses); } 9 \text { facilities } \\
\text { (various specialties) in Ontario, } \\
\text { Canada }\end{array}$ & $\begin{array}{l}\text { Qualitative secondary data } \\
\text { analysis, purposeful sampling; } \\
\text { audiotaped and transcribed, } \\
\text { individual semi-structured } \\
\text { telephone interviews }(n=32) \text {; } \\
\text { group-interviews }(n=3), \\
\text { document analysis }\end{array}$ & Not specified & $\begin{array}{l}\text { Clinical practice guideline use } \\
\text { (implementation and } \\
\text { maintenance) }\end{array}$ & \\
\hline $\begin{array}{l}\text { (Hagedorn and } \\
\text { Heideman, 2010) }\end{array}$ & $\begin{array}{l}\text { Substance abuse practitioners; } 9 \\
\text { substance use disorder clinics, } 1 \\
\text { team leader from each clinic, } \\
\text { United States }\end{array}$ & $\begin{array}{l}\text { Uncontrolled before-after-study, } \\
\text { survey (the Organizational } \\
\text { Readiness to Change } \\
\text { Assessment, ORCA } \\
\text { questionnaire) }\end{array}$ & $\begin{array}{l}\text { Organizational readiness to } \\
\text { change based on PARiHS } \\
\text { framework }\end{array}$ & $\begin{array}{l}\text { Implementation of } \\
\text { EBP/recommended practices } \\
\text { (score according to self-reported } \\
\text { survey statements at each } \\
\text { facility) }\end{array}$ & \\
\hline (Ring et al., 2005) & $\begin{array}{l}\text { Nurses; various nursing units } \\
\text { across Scotland }\end{array}$ & $\begin{array}{l}\text { Semi-structured telephone } \\
\text { interviews (13-criterion interview } \\
\text { guide); criterion-based purposive } \\
\text { sampling; } n=15 \text { nurses }\end{array}$ & $\begin{array}{l}\text { Various references, strategies } \\
\text { need to address individual, team } \\
\text { and organizational factors in } \\
\text { guideline implementation }\end{array}$ & $\begin{array}{l}\text { Implementation of evidence- } \\
\text { based nursing practice }\end{array}$ & \\
\hline $\begin{array}{l}\text { (Sandstrom et al., } \\
\text { 2011) }\end{array}$ & $\begin{array}{l}\text { Nurses from various settings; } \\
\text { Canada, Sweden, United } \\
\text { Kingdom }\end{array}$ & $\begin{array}{l}\text { Systematic review with narrative } \\
\text { synthesis ( } n=7 \text { studies included: } \\
2 \text { quantitative, } 2 \text { qualitative, } 3 \\
\text { integrative reviews) }\end{array}$ & Not applicable & EBP and research use & $\begin{array}{l}\text { Not all studies included focus } \\
\text { on leadership, various study } \\
\text { designs }\end{array}$ \\
\hline $\begin{array}{l}\text { (Schultz and } \\
\text { Kitson, 2010) }\end{array}$ & $\begin{array}{l}\text { Nurses; various wards at } 1 \text { large } \\
\text { tertiary acute care hospital in } \\
\text { South Australia }\end{array}$ & $\begin{array}{l}\text { Cross-sectional survey (ACT, } \\
\text { nursing, paper-based, slightly } \\
\text { adapted to Australian context, } \\
n=422 \text { ); } 62 \% \text { response; } 6 \text { wards } \\
\text { after evidence implementation vs } \\
6 \text { control wards }\end{array}$ & $\begin{array}{l}\text { Organizational context based on } \\
\text { PARiHS framework }\end{array}$ & $\begin{array}{l}\text { Research use (comparing units } \\
\text { that have undergone an evidence } \\
\text { implementation process with } \\
\text { control units) }\end{array}$ & $\begin{array}{l}\text { Study falsely claims causal } \\
\text { relationships (yet no baseline } \\
\text { assessment, intervention not } \\
\text { randomized) }\end{array}$ \\
\hline $\begin{array}{l}\text { (Sharp et al., } \\
\text { 2004) }\end{array}$ & $\begin{array}{l}\text { Various health care practitioners, } \\
6 \text { medical centres (teaching and } \\
\text { non-teaching tertiary hospitals, }\end{array}$ & $\begin{array}{l}\text { Qualitative study (face-to-face } \\
\text { structured interviews) conceptual } \\
\text { content analysis; } 1 \text { primary }\end{array}$ & $\begin{array}{l}\text { PARiHS framework (as a } \\
\text { heuristic for qualitative data } \\
\text { analysis) }\end{array}$ & $\begin{array}{l}\text { EBP (evidence-based program } \\
\text { including guidelines, reminders, } \\
\text { audit/feedback) }\end{array}$ & $\begin{array}{l}\text { Interview guide not available; } \\
\text { saturation for specific topics? } \\
\text { Unclear how key player was }\end{array}$ \\
\hline
\end{tabular}




\begin{tabular}{|c|c|c|c|c|c|}
\hline Author & Participants and setting & Study design & $\begin{array}{l}\text { Underlying theory, model or } \\
\text { framework }\end{array}$ & Outcome measures & Comments \\
\hline & outpatient clinics), United States & $\begin{array}{l}\text { interviewer and } 1 \text { observer; } \\
\text { interview guide with mostly } \\
\text { open-ended questions; key } \\
\text { players }(n=51)\end{array}$ & & & defined \\
\hline $\begin{array}{l}\text { (Stetler et al., } \\
\text { 2009) }\end{array}$ & $\begin{array}{l}\text { Nurses (at various levels, both } \\
\text { formal and informal leaders); } 2 \\
\text { sites (community hospital, } \\
\text { academic medical centre, } 3 \text { units } \\
\text { at each site), United States }\end{array}$ & $\begin{array}{l}\text { Mixed methods study, } \\
\text { explanatory case study; } \\
\text { comparison of } 2 \text { contrasting sites; } \\
14 \text { focus group discussions, } 59 \\
\text { leadership interviews, group } \\
\text { observations; document analysis; } \\
2 \text { separate surveys }\end{array}$ & $\begin{array}{l}\text { The Content, Context, and } \\
\text { Process model of the strategic } \\
\text { management of change; } \\
\text { differentiation between receptive } \\
\text { and non-receptive context }\end{array}$ & $\begin{array}{l}\text { Successful implementation, } \\
\text { sustainment, and normalization } \\
\text { of EBP activity }\end{array}$ & \\
\hline $\begin{array}{l}\text { (Williams et al., } \\
\text { 2011) }\end{array}$ & $\begin{array}{l}\text { healthcare Health care } \\
\text { practitioners at } 5 \text { child asthma } \\
\text { program sites (no details given), } \\
\text { United States (incl. Puerto Rico) }\end{array}$ & $\begin{array}{l}\text { Mixed methods study: self- } \\
\text { developed survey ( } n=48 \text { ); case- } \\
\text { studies and informal interviews } \\
\text { mentioned in methods section but } \\
\text { no information or results } \\
\text { presented }\end{array}$ & Not specified & $\begin{array}{l}\text { Not further specified (translation } \\
\text { of evidence-based interventions, } \\
\text { no details reported) }\end{array}$ & $\begin{array}{l}\text { Study aims unclear; poor } \\
\text { reporting; informal interviews } \\
\text { not defined; survey methods } \\
\text { not described generalizability } \\
\text { unclear; small sample size }\end{array}$ \\
\hline
\end{tabular}

PARiHS: The Promoting Action on Research Implementation in Health Services; EBP: Evidence-based practice; RU: research use/ utilization 
Table 2 Overview of review findings

\begin{tabular}{|c|c|c|c|}
\hline Author & $\begin{array}{l}\text { Reporting quality/study } \\
\text { quality }\end{array}$ & Conceptualization & Operationalization \\
\hline (Aarons, 2006) & Poor reporting quality & $\begin{array}{l}\text { Behavioural characteristics of a leader-specific leader-follower } \\
\text { interactions }\end{array}$ & $\begin{array}{l}\text { The Multifactor Leadership Questionnaire (MLQ-45 item 5X); } \\
\text { respondents' assessment of their supervisors; meso level (unit); measured } \\
\text { at individual level }\end{array}$ \\
\hline $\begin{array}{l}\text { (Bergstrom et al., } \\
\text { 2012) }\end{array}$ & $\begin{array}{l}\text { No major deficiencies } \\
\text { (high quality) }\end{array}$ & $\begin{array}{l}\text { Based on PARiHS framework (role clarity; effective teamwork; } \\
\text { effective organizational structures, democratic decision making) }\end{array}$ & $\begin{array}{l}\text { Interview guide probes into leadership support, openness to discuss } \\
\text { problems, hierarchies; meso level (unit) }\end{array}$ \\
\hline $\begin{array}{l}\text { (Boström et al., } \\
\text { 2007) }\end{array}$ & $\begin{array}{l}\text { Intermediate reporting } \\
\text { quality }\end{array}$ & $\begin{array}{l}\text { Leadership as a sub-element of context (leadership support } \\
\text { according to PARiHS framework) }\end{array}$ & $\begin{array}{l}\text { Survey items were used to operationalize these organizational factors; } \\
\text { leadership as absence or presence of support; as given by items of the } \\
\text { research utilization questionnaire: "my unit director supports research } \\
\text { utilization" }\end{array}$ \\
\hline $\begin{array}{l}\text { (Brown and } \\
\text { McCormack, } \\
\text { 2011) }\end{array}$ & $\begin{array}{l}\text { Reporting of research } \\
\text { aims and study design } \\
\text { unclear; assessment tool } \\
\text { not suitable for study } \\
\text { approach }\end{array}$ & $\begin{array}{l}\text { Leadership support as a sub-element of context (PARiHS): clarity of } \\
\text { decision- making processes, patterns of power and authority, } \\
\text { information and feedback mechanisms, active management of } \\
\text { competing priorities }\end{array}$ & $\begin{array}{l}\text { Leadership not defined a priori (e.g. interview guide not reported); not } \\
\text { clear how/whether PARiHS was used for interview guide or data analysis; } \\
\text { data from unit levels }\end{array}$ \\
\hline $\begin{array}{l}\text { (Cummings et al., } \\
\text { 2010) }\end{array}$ & $\begin{array}{l}\text { Intermediate reporting } \\
\text { quality }\end{array}$ & $\begin{array}{l}\text { Not elaborated in the article, but based on literature on act } \\
\text { development: emotionally intelligent leadership, actions of formal } \\
\text { leaders }\end{array}$ & $\begin{array}{l}\text { Providing general support: "leader handles stressful situation calmly"; } \\
\text { "looks for feedback"; "focuses on successes"; "actively mentors and } \\
\text { coaches" (see act); assessment at organizational level; scores measured at } \\
\text { individual level }\end{array}$ \\
\hline $\begin{array}{l}\text { (Damschroder et } \\
\text { al., 2011) }\end{array}$ & $\begin{array}{l}\text { Intermediate study } \\
\text { quality }\end{array}$ & $\begin{array}{l}\text { Leadership as management support: active interest and commitment; } \\
\text { engagement of management }\end{array}$ & $\begin{array}{l}\text { Interview guide: management support by mentoring, problem solving, } \\
\text { training; close-ended questions: "managers and supervisors take an active } \\
\text { interest in..."; " are strongly committed to the successful implementation } \\
\text { measured at unit level" }\end{array}$ \\
\hline $\begin{array}{l}\text { (Estabrooks et al., } \\
\text { 2007) }\end{array}$ & Poor reporting quality & Leadership as a sub-element of context (leadership support) & $\begin{array}{l}\text { Various survey items: "support for new and innovative ideas about patient } \\
\text { care"; "administration that listens and responds to employee concerns"; } \\
\text { "active staff development or continuing education program for nurses"); } \\
\text { measured both at organizational and at unit level }\end{array}$ \\
\hline $\begin{array}{l}\text { (Forsman et al., } \\
\text { 2012) }\end{array}$ & $\begin{array}{l}\text { Intermediate reporting } \\
\text { quality }\end{array}$ & $\begin{array}{l}\text { Not clearly stated in the article: management role re staff policies, } \\
\text { competence development }\end{array}$ & $\begin{array}{l}\text { Item wording not clear from article, data presented in negative wording } \\
\text { ("deficient leadership", "role ambiguity"); "staffing and skills } \\
\text { management" (NHS model); General Nordic Questionnaire for } \\
\text { Psychological and Social Factors at Work (QPSNordic), organizational } \\
\text { module: experience of leadership support from a superior (fair leadership, } \\
\text { empowering leadership) }\end{array}$ \\
\hline $\begin{array}{l}\text { (Gifford et al., } \\
\text { 2007) }\end{array}$ & High risk of bias & $\begin{array}{l}\text { Managerial leadership; behaviours and activities of managers (direct } \\
\text { and indirect influence on individuals, their environment, and } \\
\text { organizational infrastructures) }\end{array}$ & $\begin{array}{l}\text { Managers as individuals in formal management roles (includes } \\
\text { administrators, directors, executives, head nurses, and managers); } \\
\text { leadership as nurse managers' roles, behaviours or activities and their } \\
\text { influence on clinical nurses' research use }\end{array}$ \\
\hline $\begin{array}{l}\text { (Gifford et al., } \\
\text { 2006) }\end{array}$ & $\begin{array}{l}\text { Not all components of } \\
\text { assessment tool } \\
\text { applicable; some }\end{array}$ & $\begin{array}{l}\text { Behaviours and activities of nursing managers, administrators and } \\
\text { clinical resource nurses }\end{array}$ & $\begin{array}{l}\text { From data analysis: nursing leaders roles providing support by addressing } \\
\text { concerns, encouraging staff, and creating opportunities for education; } \\
\text { good communication skills; creating a positive milieu of best practices }\end{array}$ \\
\hline
\end{tabular}




\begin{tabular}{|c|c|c|c|}
\hline Author & $\begin{array}{l}\text { Reporting quality/study } \\
\text { quality }\end{array}$ & Conceptualization & Operationalization \\
\hline $\begin{array}{l}\text { (Hagedorn and } \\
\text { Heideman, 2010) }\end{array}$ & $\begin{array}{l}\text { deficiencies } \\
\text { Intermediate reporting } \\
\text { quality }\end{array}$ & $\begin{array}{l}\text { Leadership as an organizational capability to implement change } \\
\text { (aspect of organizational culture; facilitation practices; leadership } \\
\text { implementation roles) }\end{array}$ & $\begin{array}{l}\text { (influences change); meso level (unit) and organizational level } \\
\text { Leadership culture, leadership (staffing policies, communication, clear } \\
\text { definition of roles/responsibilities); leadership facilitation (practices); } \\
\text { leadership implementation roles (engagement, commitment, support); data } \\
\text { analysed at unit level }\end{array}$ \\
\hline (Ring et al., 2005) & Few deficiencies & Leadership support, not specified & $\begin{array}{l}\text { Interview guide probes into barriers of implementation; from data } \\
\text { analysis: personal authority to make changes within organization and } \\
\text { ability to motivate others; opinion vs clinical leadership: change both } \\
\text { professional attitudes and the clinical context for implementation }\end{array}$ \\
\hline $\begin{array}{l}\text { (Sandstrom et al., } \\
\text { 2011) }\end{array}$ & High risk of bias & Task- and relations-oriented leadership; behaviours & $\begin{array}{l}\text { "...the role of the person in charge, that is, the leader, and how he or she } \\
\text { can promote the process of implementing EBP in nursing" }\end{array}$ \\
\hline $\begin{array}{l}\text { (Schultz and } \\
\text { Kitson, 2010) }\end{array}$ & $\begin{array}{l}\text { Intermediate reporting } \\
\text { quality }\end{array}$ & Not elaborated in the article & $\begin{array}{l}\text { Providing general support, leader seeking feedback, acknowledges, } \\
\text { "leader handles stressful situation calmly"; data analysed at organizational } \\
\text { level }\end{array}$ \\
\hline $\begin{array}{l}\text { (Sharp et al., } \\
\text { 2004) }\end{array}$ & $\begin{array}{l}\text { Some deficiencies } \\
\text { (intermediate study } \\
\text { quality) }\end{array}$ & Not elaborated in the article & $\begin{array}{l}\text { From data analysis: leadership as a theme of facilitation (not context): } \\
\text { mediator between interventions, communication mechanisms, regularity } \\
\text { of meetings, team processes }\end{array}$ \\
\hline $\begin{array}{l}\text { (Stetler et al., } \\
\text { 2009) }\end{array}$ & $\begin{array}{l}\text { Intermediate study } \\
\text { quality }\end{array}$ & $\begin{array}{l}\text { Leadership as an element of receptivity, strategic vs operational } \\
\text { influence }\end{array}$ & $\begin{array}{l}\text { Key people leading change: influencing others to behave in certain ways } \\
\text { towards preconceived group goals, in this case EBP in a department of } \\
\text { nursing; individual and organizational level }\end{array}$ \\
\hline $\begin{array}{l}\text { (Williams et al., } \\
\text { 2011) }\end{array}$ & Poor study quality & $\begin{array}{l}\text { Not clearly defined; according to cited references: relations-oriented } \\
\text { leadership skills/behaviour and leader traits }\end{array}$ & $\begin{array}{l}\text { From survey items: innate attributes vs trainable skills and learn on the } \\
\text { job; data gathered at unit level }\end{array}$ \\
\hline
\end{tabular}

PARiHS: The Promoting Action on Research Implementation in Health Services; EBP: Evidence-based practice; RU: research use/ utilization 